\title{
INTERRELASI SPASIAL BENTUKLAHAN DENGAN VEGETASI PADA LERENG TENGGARA VULKAN CIREMAI: TINJAUAN STUDI BIOGEOMORFOLOGI
}

\author{
Oleh: \\ Arif Ashari', Baiq Ahda Razula Apriyeni' ${ }^{2}$, Deni Permana ${ }^{3}$, \\ Nur Rohmad Safarudin ${ }^{4}$ \\ 1Jurusan Pendidikan Geografi, FIS, Universitas Negeri Yogyakarta \\ 2Jurusan Pendidikan Geografi STKIP Hamzanwadi, Selong, Lombok Timur \\ ${ }^{3}$ MTsN Dadiharja Kecamatan Rancah, Kabupaten Ciamis, Jawa Barat \\ ${ }^{4}$ SMA Negeri 1 Belitang, OKU Timur, Sumatera Selatan \\ arif.ashari@uny.ac.id
}

\begin{abstract}
Abstrak
Vulkan Ciremai merupakan vulkan soliter pada zona utara Jawa Barat. Sebagai vulkan strato aktif, Vulkan Ciremai memiliki kondisi geomorfologi yang kompleks. Pengaruh iklim tropis basah dengan curah hujan tahunan tinggi menghasilkan kekayaan biodiversitas vulkan ini, khususnya jenis vegetasi. Dalam dinamika lingkungan fisik, terdapat hubungan timbal balik antara bentuklahan dengan vegetasi dimana karakteristik bentuklahan mempengaruhi distribusi spasial dan kondisi vegetasi, sebaliknya vegetasi juga mempengaruhi perkembangan bentuklahan. Tulisan ini bertujuan mendeskripsikan: (1) pengaruh faktor geomorfologis terhadap distribusi vegetasi, (2) pengaruh vegetasi terhadap proses geomorfologi, pada lereng tenggara Vulkan Ciremai, dengan tinjauan biogeomorfologi khususnya pada tema ecological topology dan ecological memory. Data dikumpulkan melalui interpretasi citra penginderaan jauh, observasi, serta studi pustaka. Faktor geomorfologis berupa bentuklahan dan proses geomorfologi diketahui berpengaruh terhadap distribusi dan karakteristik vegetasi yang ditunjukkan oleh zonasi vegetasi yang linier terhadap bentuklahan. Pengaruh vegetasi terhadap proses geomorfologi terutama nampak pada variasi kemampuan vegetasi dalam mengendalikan laju erosi dan gerakan massa.
\end{abstract}

Kata kunci: Biogeomorfologi, bentuklahan, vegetasi, Vulkan Ciremai

\begin{abstract}
Ciremai Volcano is a solitary volcano located in the northern zone of West Java. As an active stratovolcano, Ciremai has complex geomorphological conditions. Wet tropical climate with high annual rainfall result in high biodiversity, particularly the vegetation. In the dynamics of the physical environment, there is a reciprocal relationship between landform with vegetation where the characteristics of landform affects the vegetation, while vegetation affects the development of landforms. This paper aims at describing the effects of: (1) geomorphological factors on the distribution of vegetation, (2) vegetation on the geomorphological processes, at southeast flank of Ciremai Volcano, using biogeomorphological approach, particularly on the theme of ecological topology and ecological memory. Data were collected through remote sensing, observation, and literature review techniques. Geomorphological factors influence the distribution and characteristics of vegetation, indicated by vegetation zoning that is linear to landform. The
\end{abstract}


influence of vegetation on the geomorphological processes is mainly seen at variations in the ability of vegetation to control erosion and mass movements.

Keywords: Biogeomorphology, landform, vegetation, Ciremai Volcano

\section{PENDAHULUAN}

Vulkan Ciremai merupakan vulkan aktif yang terletak pada wilayah geomorfologi Zona Utara Jawa Barat. Dilihat dari kedudukannya, vulkan ini sangat unik karena merupakan vulkan soliter yang terpisah dari kompleks vulkan di Jawa Barat yang cenderung mengelompok pada zona tengah. Ciremai merupakan vulkan tipe A dengan letusan terakhir diketahui pada tahun 1937. Selang waktu istirahat terpendek selama tiga tahun dan terpanjang 112 tahun (Pannekoek, 1949; Van Bemmelen, 1949; Van Padang, 1983; Badan Geologi, 2014). Vulkan Ciremai bertipe stratovulkano yang dapat diidentifikasi dengan bentuk kerucut sempurna, yang berkembang pada bekas erupsi terdahulu dengan batuan yang lebih tua. Morfologi Vulkan Ciremai meliputi bentuklahan kepundan, kerucut vulkan, lereng vulkan, kaki vulkan, serta dataran kaki vulkan. Pada lereng tenggara juga terdapat bagian dari bingkai kaldera gegerhalang yang secara morfologis teridentifikasi sebagai igir vulkanik, serta medan lava.

Letak Vulkan Ciremai yang berada pada zona utara Jawa Barat menyebabkan vulkan ini terpengaruh oleh fenomena monsun, dengan curah hujan tahunan tinggi hingga mencapai $1949 \mathrm{~mm}$ pada tahun 2015 (BPS Kabupaten Kuningan, 2016). Pengaruh lingkungan iklim tropis basah dengan curah hujan tahunan tinggi ditambah interaksinya dengan faktor geologis dan geomorfologis menghasilkan kekayaan biodiversitas khususnya pada jenis vegetasi. Van Steenis (2010) menjelaskan kondisi yang selalu basah hampir sepanjang tahun memungkinkan berkembangnya flora yang kaya di Jawa Barat. Namun demikian, khusus pada bagian utara Jawa Barat juga cukup banyak memiliki jenisjenis tumbuhan musiman sebagai pengaruh dari kondisi iklim musiman yang dikenal di wilayah tersebut.

Dalam dinamika lingkungan fisik suatu wilayah terdapat hubungan saling mempengaruhi antara bentuklahan dengan vegetasi. Bentuklahan dalam kaitannya dengan kondisi iklim dan material penyusunnya berpengaruh terhadap perkembangan dan persebaran keruangan jenis vegetasi tertentu. Sebaliknya, jenis vegetasi yang berkembang pada suatu bentuklahan juga mempengaruhi perkembangan bentuklahan misalnya pada proses pelapukan serta denudasi. Dengan kondisi bentuklahan dan vegetasi yang kompleks pada lereng tenggara Vulkan Ciremai, menarik untuk dikaji bagaimana interrelasi spasial yang terbentuk antara bentuklahan dan vegetasi yang bervariasi pada wilayah tersebut. Interrelasi spasial juga menggambarkan sejauh mana peran dari komponen geomorfik dan ekologi dalam membentuk sistem di permukaan bumi khususnya pada bentanglahan vulkanik di daerah tropis.

Hubungan antara komponen geomorfik dan ekologis yang bersifat sirkular secara khusus dikaji dalam biogeomorfologi. Biogeomorfologi mengkombinasikan antara kajian geomorfologi dengan ekologi dengan pembahasan yang mendalam pada hubungan 
timbal balik antara bentanglahan dengan vegetasi, tidak hanya sekedar memperhatikan pengaruh lingkungan fisik terhadap organisme. Dalam biogeomorfologi organisme merupakan salah satu faktor yang memiliki peranan penting dalam pembentukan dan perkembangan bentuklahan. Namun demikian meskipun organisme memiliki peran dalam perkembangan bentuklahan, dibandingkan dengan faktor lain seperti iklim, topografi, litologi, dan struktur geologi, peranan faktor organisme relatif belum mendapatkan tekanan yang sepadan (Sutikno, 1992; Baptist, 2005; Stallins, 2006). Berdasarkan kondisi tersebut tulisan ini diharapkan dapat memberikan sumbangan dalam kajian biogeomorfologi di Indonesia khususnya pada bentanglahan vulkanik.

Sutikno (1992) lebih lanjut menjelaskan bahwa biogeomorfologi selain mempunyai arti penting ilmiah juga mempunyai arti penting terapan. Berkaitan dengan hal tersebut, pembahasan mengenai kondisi biogeomorfologis lereng tenggara Vulkan Ciremai diharapkan dapat memberikan gambaran distribusi vegetasi kaitannya dengan bentuklahan. Informasi ini sangat penting berkaitan dengan upaya identifikasi potensi sumberdaya hayati yang terdapat pada Vulkan Ciremai, baik untuk tujuan pemanfaatan maupun pelestarian. Disisi lain informasi peran vegetasi terhadap proses geomorfologi juga memberikan referensi bagi perencanaan pengelolaan lingkungan secara lebih luas. Perencanaan pengembangan dan konservasi pada bentanglahan vulkanik memerlukan informasi yang lengkap mengenai karakteristik bentuklahan, kondisi sumberdaya hayati yang ada, serta interaksinya sebagai bagian dari ekosistem vulkan. Pengembangan dan konservasi bentanglahan vulkanik pada saat ini merupakan salah satu isu strategis yang menjadi salah satu agenda dalam sustainable development goal's untuk menciptakan tata kehidupan yang lebih baik pada masa mendatang.

\section{KONDISI GEOMORFOLOGIS LERENG TENGGARA VULKAN CIREMAI}

Pembahasan mengenai kondisi geomorfologis tidak terlepas dari aspek kajian geomorfologi yang meliputi bentuklahan, proses geomorfologi, evolusi pertumbuhan bentuklahan, dan hubungan geomorfologi dengan lingkungan (Mangunsukardjo, 1984). Thornbury (1959) menjelaskan bahwa bentuklahan merupakan bagian yang sangat penting karena proses geomorfologi yang terjadi akan berkembang sesuai dengan watak bentuklahannya. Selanjutnya untuk melakukan berbagai kajian dalam geomorfologi dapat berpegang kepada beberapa konsep dasar geomorfologi (Pramono dan Ashari, 2014). Lereng tenggara Vulkan Ciremai yang diamati dalam penulisan ini terdiri dari bentuklahan kepundan gunungapi, kerucut gunungapi, lereng gunungapi, kaki gunungapi, dataran kaki gunungapi, igir vulkanik, dan medan lava (Gambar 1). Berbagai bentuklahan tersebut memiliki variasi relief, struktur, batuan penyusun, serta proses geomorfologi yang terjadi pada saat ini.

Bentuklahan kepundan gunungapi terletak pada bagian paling atas dari morfologi kerucut stratovulkano, dengan ciri-ciri berupa depresi pada puncak kerucut vulkan. Wilayah ini merupakan pusat aktivitas vulkanik Ciremai. Badan Geologi (2014) menjelaskan Vulkan Ciremai mempunyai tiga kawah yaitu Kawah Barat, Kawah Timur, dan Gua Walet. Kawah Barat dan Kawah Timur terletak pada depresi kepundan, sedangkan Gua Walet berupa depresi kecil yang terletak pada bagian tepi kepundan berbatasan dengan bentuklahan kerucut vulkan di bawahnya. Berdasarkan pengamatan lapangan, Gua Walet relatif tidak 
aktif dibandingkan dengan Kawah Barat dan Kawah Timur. Bentuklahan kepundan gunungapi dalam pembagian fasies gunungapi termasuk dalam fasies sentral yang tersusun oleh hasil pengendapan material lava dan piroklastik. Berdasarkan genesisnya kepundan gunungapi terbentuk oleh proses erupsi. Proses geomorfolgi yang berlangsung saat ini selain aktivitas vulkanik pada kawah, adalah gerakan massa berupa longsoran batuan pada sisi bagian dalam kepundan. Kondisi bentuklahan kepundan gunungapi ditunjukkan pada Gambar 2.

Bentuklahan kerucut gunungapi terletak di bawah kepundan gunungapi dengan ciri bentuk kubah dengan lereng paling curam. Berdasarkan klasifikasi fasies gunungapi bentuklahan ini termasuk dalam fasies piroksimal. Bentuklahan kerucut gunungapi pada sisi tenggara Vulkan Ciremai tersusun oleh material lava dan piroklastik. Verstappen (2013) menjelaskan bahwa kerucut gunungapi terbentuk oleh proses pengendapan abu atau abu klastik yang berasal dari hancuran sumbat lava, jatuhan atau longsor di bawah pengaruh gravitasi. Pada saat ini material yang diendapkan pada kerucut gunungapi mulai mengalami perombakan oleh limpasan permukaan. Selain itu juga terdapat proses geomorfologi berupa pelapukan batuan.

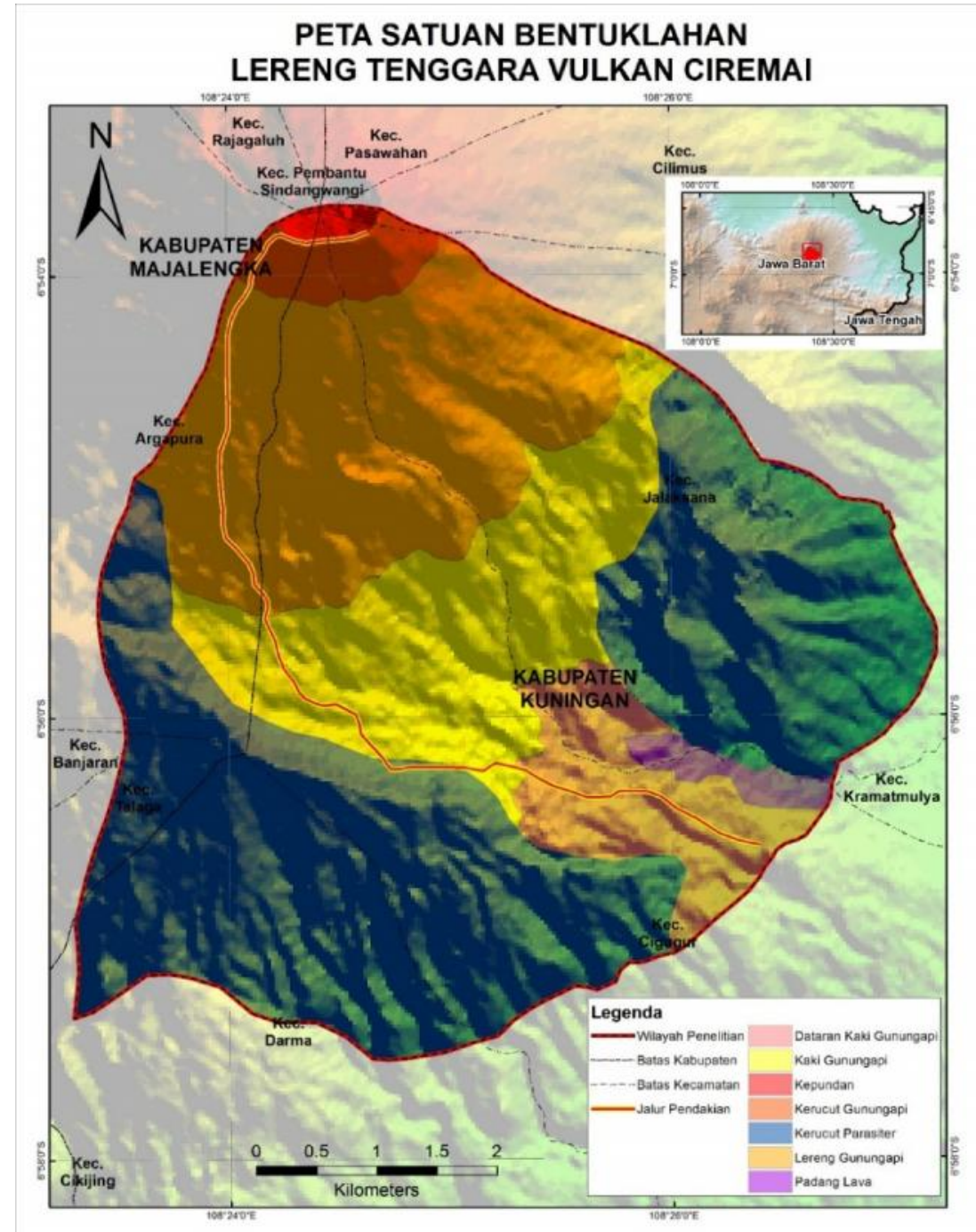

Gambar 1. Peta satuan bentuklahan lereng tenggara Vulkan Ciremai 


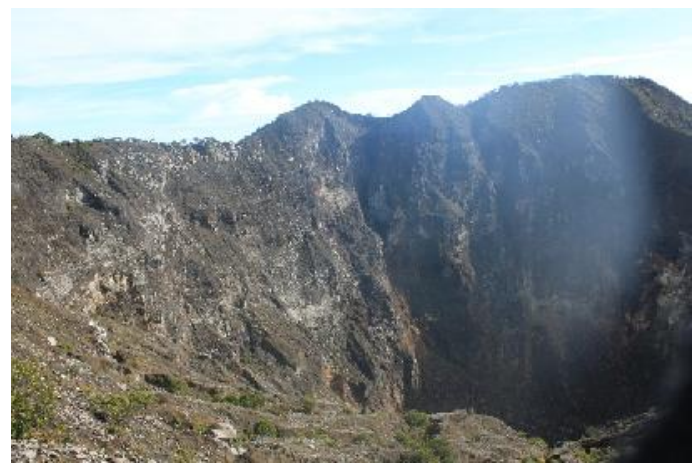

A

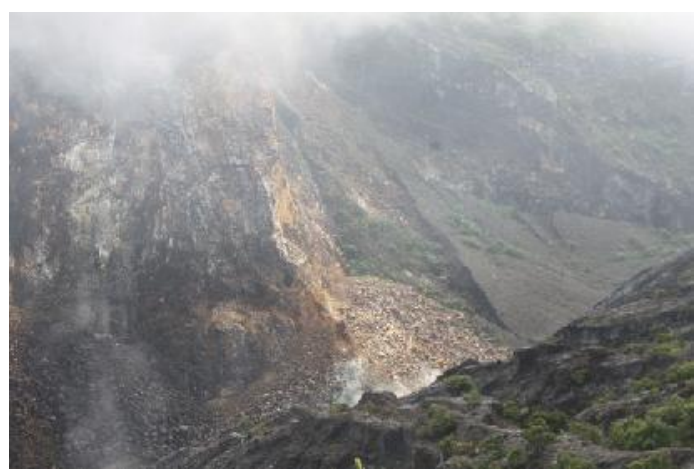

C

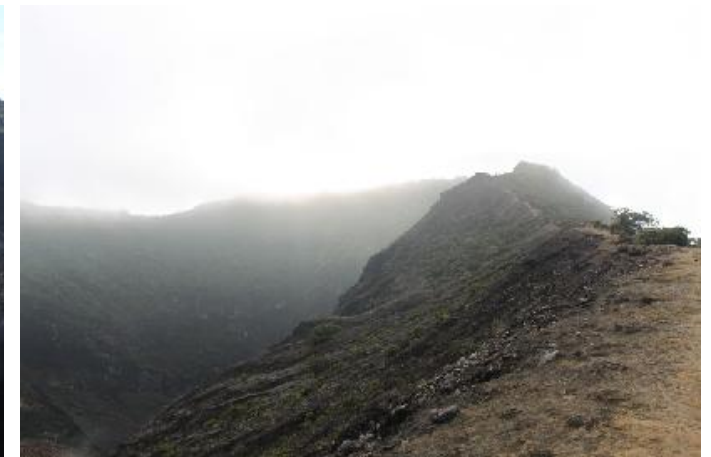

B

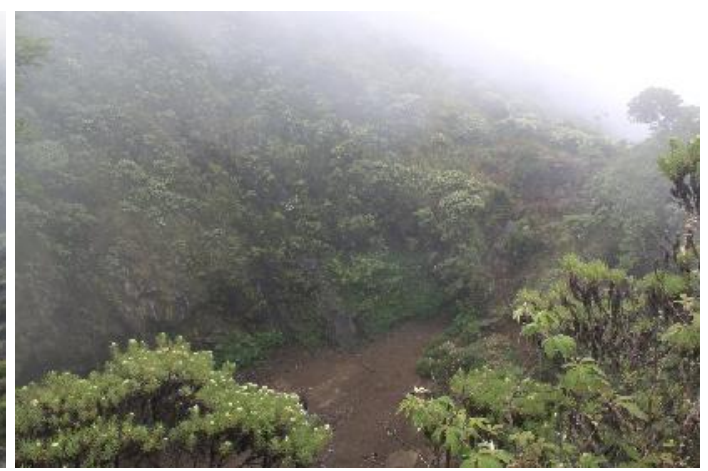

D

Gambar 2. Bentuklahan kepundan Vulkan Ciremai. A: dinding kepundan barat, B: dinding kepundan timur, C: Longsor pada dinding kepundan, D: Kawah Gua Walet (Sumber: Data Lapangan, 2016)

Lereng gunungapi terletak di bawah kerucut gunungapi, biasanya dibedakan menjadi lereng atas, lereng tengah, dan lereng bawah. Bentuklahan ini memiliki ciri-ciri lereng miring, bentuk lereng bervariasi dari lurus hingga cekung, serta relief berbukit. Berdasarkan klasifikasi fasies gunungapi bentuklahan ini termasuk dalam fasies piroksimal pada bagian lereng atas dan fasies medial pada bagian lereng tengah hingga bawah. Bentuklahan ini tersusun oleh endapan piroklastik dan endapan lahar. Proses yang berlangsung saat ini berupa pelapukan dan erosi dalam bentuk erosi lembar, alur, dan parit. Tipe dan laju erosi dipengaruhi oleh kondisi vegetasi pada bentuklahan tersebut.

Bentuklahan kaki gunungapi memiliki kemiringan landai hingga miring dengan unit relief berombak hingga bergelombang. Adapun bentuklahan dataran kaki gunungapi memiliki unit relief landai. Bentuklahan ini tersusun oleh material lahar serta sebagian tersusun oleh material lava hasil aktivitas vulkanik Ciremai pada periode yang lebih tua. Bentuklahan kaki gunungapi dimanfaatkan sebagai kawasan hutan dan pertanian, sedangkan dataran kaki gunungapi dimanfaatkan sebagai kawasan pertanian dan permukiman. Penggunaan untuk pertanian tegalan berpengaruh terhadap tingkat erosi pada bentuklahan ini. 


\section{INTERRELASI SPASIAL BENTUKLAHAN DENGAN VEGETASI}

Berdasarkan hasil analisis diketahui terdapat hubungan saling mempengaruhi antara kondisi geomorfologis dengan vegetasi pada lereng tenggara Vulkan Ciremai. Faktor geomorfologis merupakan salah satu faktor yang mempengaruhi distribusi vegetasi. Hal ini disebabkan oleh pengaruh ketinggian tempat yang berkaitan dengan iklim mikro di wilayah tersebut, jenis material penyusun, serta proses geomorfologi yang berlangsung yang mempengaruhi pertumbuhan vegetasi. Sebaliknya, kondisi vegetasi juga mempengaruhi proses geomorfologi yang terjadi pada suatu bentuklahan.

Bentuklahan kepundan gunungapi terletak pada ketinggian tempat mencapai 3078 mdpal, dengan dipengaruhi oleh proses vulkanisme yang masih aktif dari kawah barat dan kawah timur Ciremai. Pada bentuklahan ini hanya dijumpai beberapa jenis vegetasi perintis yaitu Cantigi gunung (Vaccinium varingiaefolium) dan Edelweiss (Anaphalis Javanica dan Anaphalis viscida). Van Steenis (2010) menjelaskan bahwa berdasarkan elevasinya, bentuklahan kepundan ini termasuk dalam zona sub alpin di atas batas hutan dengan ditandai vegetasi rendah, kerapatan tinggi, lebih terang daripada hutan di bawahnya, berbatang kurus, dan berkanopi agak rata. Namun demikian karena kepundan Ciremai terpengaruh oleh proses vulkanisme aktif, maka kondisi vegetasi pada wilayah ini tidak hanya dipengaruhi oleh ketinggian tempat tetapi juga berkombinasi dengan pengaruh vulkanisme yang aktif.

Pengaruh vulkanisme nampak pada distribusi vegetasi yang tidak merata dan kondisi vegetasi yang bervariasi pada bentuklahan kepundan gunungapi. Pada bagian lereng luar kepundan, vegetasi dijumpai lebih banyak, lebih rapat, lebih tinggi, dengan diameter batang lebih besar, dibandingkan dengan lereng bagian dalam kepundan dengan vegetasi yang hanya dijumpai setempat-setempat dan lebih kerdil. Pada bagian kawah yang lebih aktif sangat miskin vegetasi, sedangkan bagian kawah yang tidak aktif vegetasi mulai berkembang masuk ke lereng dalam kepundan membentuk kumpulan vegetasi berkanopi rendah dengan kerapatan relatif tinggi (Gambar 3). Mengenai kondisi ini, Van Steenis (2010) menjelaskan bahwa pada sekitar kepundan yang memiliki keasaman tinggi, penciuman manusia sangat peka terhadap gas belerang hingga jarak $1 \mathrm{~km}$, namun demikian kondisi ini masih cukup lemah untuk merusak vegetasi sehingga vegetasi masih dapat hidup. Tumbuhan pionir yang sangat kerdil dan tumbuh merunduk dapat berkembang khususnya pada lokasi-lokasi yang terlindung dari angin dan gas beracun. Apabila kawah tidak aktif lagi maka vegetasi pionir akan menyelinap masuk yang kemudian dapat berkembang menjadi hutan elfin cantigi, sementara itu pada kawah aktif semburan gas dapat memusnahkan vegetasi yang baru terbentuk. Dengan proses geomorfologi didominasi oleh vulkanisme serta longsoran pada tebing dalam kepundan, sementara vegetasi yang tumbuh relatif terbatas maka pengaruh vegetasi terhadap proses geomorfologi belum cukup signifikan pada bentuklahan kepundan gunungapi.

Bentuklahan kerucut gunungapi terletak pada ketinggian 2700 mdpal hingga dibawah kepundan pada ketinggian 3000 mdpal. Bentuklahan ini juga termasuk ke dalam zona sub alpin yang dicirikan oleh hutan rendah rapat dengan pohon-pohon tinggi menyendiri, sering berlumut, atau terdapat konifera (Van Steenis, 2010). Jenis vegetasi yang 
terdapat pada bentuklahan ini lebih sedikit bervariasi dibandingkan dengan bentuklahan kepundan gunungapi namun perkembangannya relatif masih terbatas. Vegetasi yang dijumpai masih didominasi oleh Cantigi gunung (Vaccinium varingiaefolium) dan Edelweiss (Anaphalis Javanica dan Anaphalis viscida) serta mulai terdapat kemlandingan gunung (Albizzia lophanta) dan Astronia spectabilis. Solum tanah yang tipis pada bentuklahan ini diduga berpengaruh terhadap distribusi vegetasi yang kurang merata. Proses geomorfologi berupa erosi alur dan parit banyak terjadi pada bentuklahan ini dan pada beberapa bagian tidak mampu dihambat oleh vegetasi.

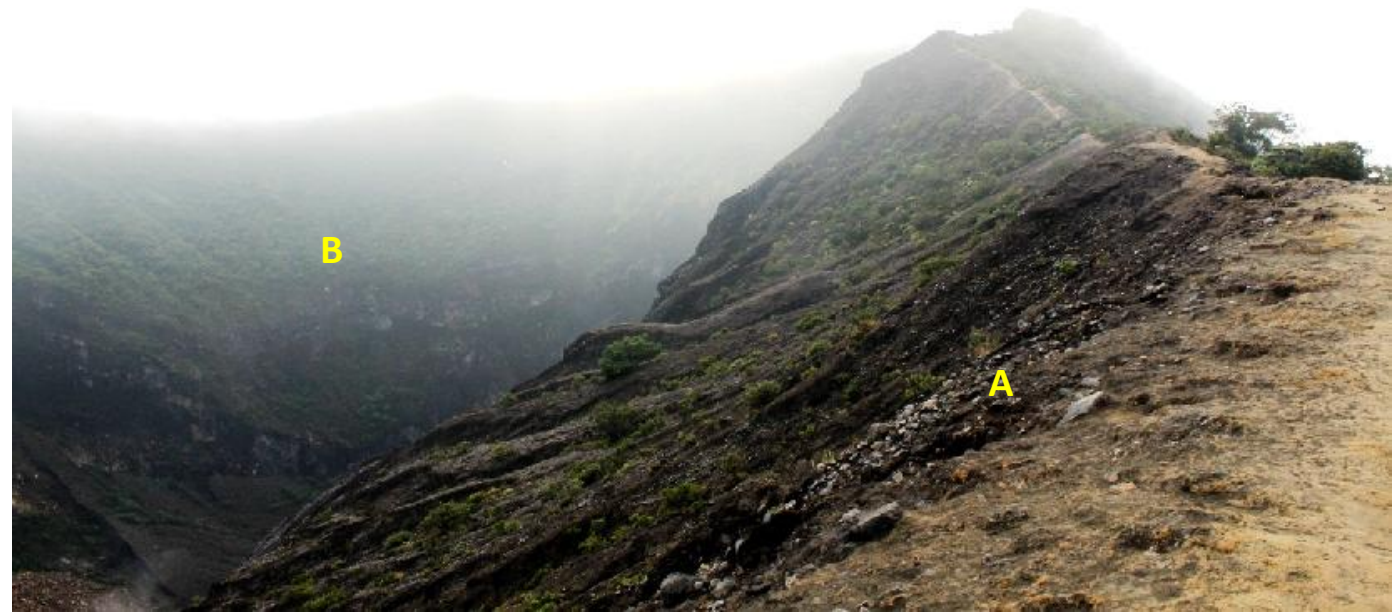

Gambar 3. Kondisi vegetasi pada bentuklahan kepundan gunungapi Ciremai. Bagian A berbatasan langsung dengan bagian kawah yang aktif dicirikan oleh vegetasi kerdil dan mengelompok. Bagian B pada bagian kawah yang tidak aktif dicirikan oleh vegetasi yang meluas membentuk kumpulan vegetasi berkanopi rendah dengan kerapatan tinggi (Sumber: Data Lapangan, 2016)

Bentuklahan lereng gunungapi memiliki kondisi vegetasi yang sangat bervariasi. Bentuklahan ini berada pada ketinggian 1800 mdpal hingga di bawah kerucut gunungapi pada ketinggian 2700 mdpal. Mulyasana (2008) dalam penelitiannya menemukan jenis vegetasi yang mendominasi lereng gunungapi pada ketinggian dibawah 2400 mdpal antara lain Litsea sp, Schima wallichi, Vermonia arborea, Ficus fistulosa, Palaquium rostratum, Alchornea rugosa, dan Queercus sundaica, sedangkan pada ketinggian diatas 2400 mdpal terdapat Leuncanea glauca, Palaqium rostatum, Vaccinium varingiaefolium, P. rostatum, dan Ficus ampelas.

Van Steenis (2010) menjelaskan, bagian lereng bawah dan lereng tengah yang terletak di bawah ketinggian 2400 mdpal termasuk dalam zona pegunungan dengan ciri hutan tertutup berbatang pohon tinggi dan miskin lumut, sedangkan bagian lereng atas yang terdapat pada ketinggian diatas 2400 mdpal termasuk dalam zona subalpin dengan ciri hutan rendah rapat dengan pohon-pohon tinggi menyendiri, sering berlumut atau terdapat konifera. Pada wilayah sekitar ketinggian 2600 mdpal terdapat hutan elfin yang dicirikan oleh hutan kanopi rendah dengan pohon tumbuh rapat dan berbatang bengkok dan berlumut. Hutan elfin di bagian tenggara Vulkan Ciremai tidak terlalu luas cakupan 
wilayahnya bila dibandingkan dengan vulkan lain di Jawa Barat seperti Gede-Pangrango, diduga dipengaruhi oleh faktor curah hujan di wilayah ini yang lebih rendah dari wilayah Jawa Barat pada umumnya, serta adanya pengaruh dari pola iklim monsun.

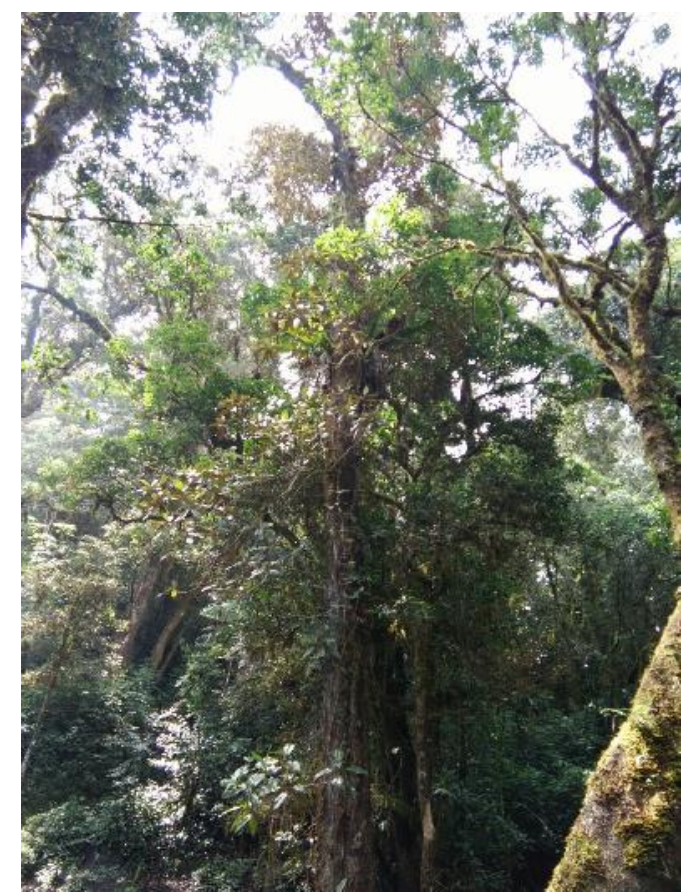

Gambar 4. Vegetasi pada bentuklahan lereng gunungapi pada ketinggian dibawah 2400 mdpal dengan ciri vegetasi besar, rapat, berbatang pohon tinggi, dan sedikit berlumut. (Sumber: Data Lapangan, 2016)

Pengaruh vegetasi pada bentukahan lereng gunungapi ini nampak jelas dalam menghambat proses erosi. Vegetasi hutan dengan kanopi rapat sangat efektif dalam proses intersepsi air hujan yang selanjutnya dialirkan sebagai aliran batang hingga mencapai permukaan tanah yang banyak dilapisi oleh seresah. Karena kemampuannya dalam mengurangi erosivitas hujan ini maka pada bentuklahan lereng gunungapi tidak dijumpai erosi percik. Bentuk erosi yang dijumpai umumnya berupa erosi lembar dan erosi alur. Proses pelapukan didominasi oleh dekomposisi batuan. Kondisi ini sangat berbeda dengan bentuklahan kepundan maupun kerucut gunungapi yang banyak terjadi proses disintegrasi batuan.

Pada bentuklahan yang terletak pada ketinggian di bawah 1800 mdpal yaitu kaki gunungapi, medan lava, dan dataran kaki gunungapi, kondisi vegetasi relatif sama yaitu terdapat hutan tertutup dengan batang pohon tinggi dan sedikit lumut yang termasuk pada zona pegunungan atau subzona subpegunungan. Pada wilayah ini antara lain terdapat Symplocos javanica, Acemena acuminatissima, Schima walichii, Litsea sp, Antidesma tetrandum, Ficus fistulosa, Castanopsis argenta, dan Queercus sundaica. Sebagian dari wilayah bentuklahan kaki gunungapi dimanfaatkan sebagai lahan pertanian dengan sedikit vegetasi besar yang menutupi lahan sehingga terjadi erosi lebih besar dibandingkan 
bagian hutan. Proses geomorfologi lainnya berupa gerakan massa longsoran yang terjadi pada lembah-lembah aliran yang mulai banyak terbentuk pada bentuklahan kaki gunungapi.

Stallins (2006) mengacu kepada Parker dan Bendix (1996) menekankan perlunya pemahaman yang lebih baik tentang bagaimana interaksi biogeomorfik bervariasi secara geografis. Berkaitan dengan hal tersebut dikembangkan konsep ecological topology yang digunakan untuk konsep hubungan spasiotemporal dalam sistem biogeomorfik. Vulkan ciremai sebagai dengan tipe stratovulkano memiliki kondisi biogeomorfologis yang menunjukkan hubungan sebab akibat antara karakteristik bentanglahan vulkanik dengan kondisi vegetasinya. Hubungan tersebut dikendalikan oleh demarkasi bentuklahan dan ketinggian tempat. Bentuklahan pada ketinggian tempat rendah akan berpengaruh terhadap karakteristik vegetasinya sehingga berbeda dengan ketinggian tempat yang lebih tinggi. Bentuklahan pada ketinggian tempat yang sama namun memiliki proses geomorfologi yang berbeda, khususnya berkaitan dengan vulkanisme aktif, juga memiliki karakteristik yang berbeda.

Ecological memory adalah tema lain yang menonjol yang mengikat geomorfologi dan ekologi bersama-sama di bawah kerangka kompleksitas. Dalam ecological memory gangguan dapat ditandai pengaruhnya dalam kelimpahan dan pola spasial vegetasi dan topografi di seluruh bentanglahan. Selain faktor ketinggian tempat dan proses geomorfologi yang berlangsung saat ini, distibusi spasial vegetasi pada Vulkan Ciremai juga dipengaruhi oleh kondisi tanah baik ketebalan solum tanah maupun tingkat perkembangan tanahnya. Perkembangan vegetasi relatif terhambat di daerah dengan solum tanah tipis yang baru berkembang pada jenis batuan yang relatif lambat mengalami pelapukan seperti endapan lava. Perkembangan tanah dipengaruhi oleh proses erupsi masa lampau yang berperan dalam peremajaan material di beberapa tempat. Karena proses erupsi masa lampau secara tidak langsung berpengaruh terhadap kelimpahan dan distribusi spasial vegetasi, maka dalam pendekatan ecological memory proses erupsi ini merupakan gangguan yang ditandai yang berpengaruh terhadap kondisi biogeomorfologi Vulkan Ciremai.

\section{SIMPULAN}

Berdasarkan pemaparan diatas dapat diambil beberapa kesimpulan antara lain: (1) Vulkan Ciremai sebagai bentanglahan vulkanik strato dengan pusat erupsi tunggal dan terletak pada daerah iklim monsun memiliki karakteristik biogeomorfologis yang spesifik. Kondisi biogeomorfologis ini menunjukkan hubungan yang saling mempengaruhi antara bentuklahan dengan vegetasi. Variasi ketinggian tempat pada vulkan strato dan proses geomorfologi merupakan faktor yang berpengaruh terhadap distribusi vegetasi, sebaliknya kondisi vegetasi juga berpengaruh terhadap proses geomorfologi yang berlangsung pada saat ini terutama erosi dan gerakan massa. (2) aktivitas vulkanisme pada masa lampau merupakan gangguan yang ditandai yang berpengaruh terhadap kondisi biogeomorfologi. Hal ini karena vulkanisme masa lampau juga berpengaruh terhadap kelimpahan dan distribusi vegetasi, walaupun tidak berpengaruh secara langsung melainkan melalui 
pengaruhnya terhadap kondisi tanah. Hubungan yang saling mempengaruhi antara bentuklahan dengan vegetasi menunjukkan adanya interrelasi spasial yang menghasilkan sistem biogeomorfologis pada bentanglahan vulkanik.

\section{UCAPAN TERIMA KASIH}

Dalam kesempatan ini penulis mengucapkan terima kasih kepada berbagai pihak yang telah berperan dalam proses penulisan ini. Penulis juga mengucapkan terima kasih kepada bidang kemahasiswaan FIS UNY dan para mahasiswa komunitas MPA Mahameru FIS UNY yang telah bersama-sama melakukan pengamatan di lapangan selama pendakian di Vulkan Ciremai melalui kegiatan Triarga Jawadwipa Scientific Expedition, sehingga dapat diperoleh berbagai informasi dari lapangan yang mendukung terselesaikannya tulisan ini.

\section{DAFTAR PUSTAKA}

Badan Geologi. 2014. Gunung Ciremai Jawa Barat. http://www.vsi.esdm.go.id/index.php/gunungapi/data-dasar-gunungapi/527-gciremai diakses 17 Agustus 2016.

Baptist, M.J. 2005. Modelling Floodplain Biogeomorphology. Delft: DUP Science.

BPS Kabupaten Kuningan. 2016. Kabupaten Kuningan dalam Angka 2016. https://kuningankab.bps.go.id/index.php/publikasi/137 diakses 17 Agustus 2016.

Mangunsukardjo, K. 1984. Geomorfologi dan Terapannya. Pidato Pengukuhan Jabatan Lektor Kepala dalam Geomorfologi Terapan pada Fakultas Geografi, Universitas Gadjah Mada. Fakultas Geografi, Universitas Gadjah Mada 1 Desember 1984.

Mulyasana, D. 2008. Kajian Keanekaragaman Jenis Pohon pada Berbagai Ketinggian Tempat di Taman Nasional Gunung Ciremai Propinsi Jawa Barat. Skripsi. Fakultas Kehutanan Institut Pertanian Bogor.

Pannekoek, A.J. 1949. Outline of the Geomorphology of Java. Leiden: EJ Brill.

Pramono, H. dan Ashari, A. 2014. Geomorfologi Dasar. Yogyakarta: UNY Press.

Stallins, J.A. 2006. Geomorphology and Ecology: Unifying Themes for Complex Systems in Biogeomorphology. Geomorphology 77 (2006): 207-216.

Sutikno. 1992. Biogeomorfologi dan Prospeknya di Indonesia. Yogyakarta: Fakultas Geografi Universitas Gadjah Mada.

Van Bemmelen, R.W. 1970. The Geology of Indonesia, Vol IA General Geology of Indonesia and Adjacent Archipelagoes. The Hague: Goverment Printing Office.

Van Padang, M.N. 1983. History of the Volcanology in the Former Netherlands East Indies. Scripta Geol 71 (1983): 1-76.

Van Steenis, C.G.G.J. 2010. Flora Pegunungan Jawa. Bogor: LIPI Press.

Verstappen, H. Th. 2013. Garis Besar Geomorfologi Indonesia. Yogyakarta: Gadjah Mada University Press. 